\title{
ELEMENTOS DO GÓTICO FICCIONAL EM DESALMA
}

Wellington Oliveira de Souza

Recebido em 18 fev 2021. Wellington Oliveira de Souza

Aprovado em 22 mar 2021. Doutorando pelo Programa de Pós-Graduação em Estudos Literários - PPGEL, da Universidade do Estado de Mato Grosso - UNEMAT. Bolsista CAPES.

wellington.os17@gmail.com https://orcid.org/0000-0003-2609-612X

Resumo: Este estudo objetiva analisar a série Desalma à luz do Gótico ficcional, partindo de alguns elementos, tais como o locus horribilis e o passado que volta para assombrar o presente, ambos revestidos pela atmosfera negativa. Desalma chama atenção pela grande produção e a forte presença do terror e suspense, responsáveis pela experiência do medo no espectador, que vivencia e experimenta acontecimentos originários de espaços inóspitos e imbricados ao sobrenatural.

Palavras-chave: Desalma. Gótico ficcional. locus horribilis. Terror. Horror.

Abstract: This study aims to analyze the series Desalma under the light of gothic, considering some key elements existing in the gothic machinery, such as locus horribilis and the past that returns to haunts the present, both covered by the negative 
atmosphere that characterizes the gothic. Desalma calls the attention by its great production and the presence of the terror and suspense, responsible for the experience of fear in the viewer, who experiences the events originating from inhospitable spaces imbricated to the supernatural.

Keywords: Desalma. Gothic. loci horribiles. Terror. Fear.

\section{INTRODUÇÃO}

Ao olharmos para a historiografia literária e tentarmos identificar as origens do modo/gênero Gótico, corremos o risco de limitá-lo apenas a um tempo e espaço históricos. No entanto, não podemos negar que a ideia de origem lança-nos para a Inglaterra, mais especificamente a partir de meados do século XVIII, quando os 'Graveyard poets' (Poetas de cemitério) produziam seus textos tendo como elementos centrais ruínas, cemitérios, morte, escuridão etc. Sem dúvida, iniciaram um percurso que, logo em seguida, ganhou maiores contornos através do romance seminal The castle of Otranto (O castelo de Otranto) (1764-1765), de Horace Walpole, que intensificou ainda mais as questões iniciadas pelos poetas.

Desde então, escritores vindouros embarcaram nessa esteira de produção, podemos citar alguns: Ann Radcliffe, Matthew Gregory Lewis, Edgar Allan Poe, Mary Shelley, entre vários outros, que investiram e fortaleceram o caminho trilhado pelos poetas e por Horace Walpole, criando, portanto, uma tradição do gótico, que logo foi buscada pelo teatro e pelo cinema, também pelo rádio e televisão (a partir do início da década de 1950), fundamentais para as adaptações literárias e para o surgimento de novos formatos, como a série televisiva ou seriados, em que 
contemplamos mecanismos e estratégias difundidas pelos artistas da tradição gótica.

De acordo com Helen Wheatley, "[...] the latter part of the twentieth century (and, arguably, the beginning of the twentyfirst) has seen a general diffusion of the Gothic genre across a wide range of cultural sites, a relative explosion of Gothic images and narratives which has prompted a renewed critical interest in the genre"1 $^{\prime 1}$ (2002, p. 33). É pensando no percurso do gótico ficcional e nas relações intersemióticas, cada vez mais presentes no século $X X I$, entre literatura, teatro, cinema e televisão, que chegamos na série Desalma, um drama sobrenatural que aposta no terror. Essa série foi lançada em 22 de outubro de 2020, pela plataforma de streaming Globoplay², pertencente à emissora brasileira de televisão Rede Globo.

Com base nessas observações, este estudo objetiva analisar a série Desalma à luz do Gótico ficcional, partindo de alguns elementos, tais como o locus horribilis e o passado que volta para

1 A última parte do século $X X$ (e, possivelmente, o início do XXI) viu uma difusão geral do gênero Gótico em uma ampla gama de espaços culturais, uma explosão relativa de imagens e narrativas góticas que gerou uma renovação de interesse crítico no gênero (WHEATLEY, 2002, p. 33, todas as traduções do presente estudo foram feitas por mim).

2 De acordo com o site imprensa, "o Globoplay é a maior plataforma brasileira de streaming, com oferta de conteúdo gratuito e exclusivo para assinantes. Com mais de 840 títulos publicados em 2019 e cerca de 115 milhões de horas de consumo por mês, o serviço reúne conteúdos originais Globo e do mercado audiovisual independente, filmes e séries internacionais renomadas, dentre elas produções exclusivas, que só serão exibidas online. A plataforma conta ainda com uma oferta completa com os canais lineares da Globo através do Globoplay + canais ao vivo, que agrega em um só lugar, além da TV Globo, o Multishow, Globonews, Sportv 1, Sportv 2, Sportv 3, GNT, Viva, Gloob, Gloobinho, Off, Bis, Mais Na Tela, Megapix, Universal TV, Studio Univeral, SYFY, Canal Brasil e Futura. Tudo junto, na mais completa e variada oferta de conteúdo para que o público acesse a qualquer momento e de onde estiver o que está no ar, o que já foi ao ar e o que ainda será exibido". Disponível em: https://imprensa.globo.com/programas/ desalma/textos/a-construcao-da-ivana-kupala-em-desalma/. Acesso em: 05 jan. 2021. 
assombrar o presente, ambos revestidos pela atmosfera negativa. Desalma chama atenção pela grande produção e a forte presença do terror e suspense, responsáveis pela experiência do medo no espectador, que vivencia e experimenta acontecimentos originários de espaços inóspitos e imbricados ao sobrenatural.

\section{GÓTICO FICCIONAL}

Sem dúvida, The castle of Otranto (O castelo de Otranto) (17641765), de Horace Walpole, é obra seminal para pensarmos o gótico no plano literário. Todavia, não podemos esquecer da produção existente pouco antes de Walpole, observada por Fred Botting (2014, p. 30) e Nöel Carroll (1999, p. 16) como 'Graveyard poetry' (Poesia de cemitério), muito popular na Inglaterra na primeira metade do século XVIII e que contribuiu diretamente para o Gothic revival (Revivalismo gótico), movimento marcado por um forte sentimento afetivo pelo estilo medieval.

Conforme Botting (2014), embora muitas construções arquitetônicas na Inglaterra do século das luzes se filiassem às características da arquitetura medieval, foram as obras literárias que pavimentaram de maneira concreta o sentimento afetivo pelo passado. Para o autor, "Antiquarianism, the vogue for the Graveyard school of poetry and intense interest in the sublime were significant features of the cultural environment that nurtured the gothic revival”3 (BOTTING, 2014, p. 30). O revivalismo gótico se tornou uma sombra capaz de assustar os valores neoclássicos que orientavam o período.

3 O antiquarianismo, a moda da escola de poesia de cemitério e o intenso interesse pelo sublime foram características significativas do ambiente cultural que alimentou 0 renascimento gótico (BOTTING, 2014, p. 30). 
A poética principal que regia a poesia de cemitério constituíase através dos seguintes elementos: sepulturas, cemitérios, noite, ruínas, morte e fantasmas. Alguns nomes e poemas se destacam nesse momento, como Nathaniel Cotton, com Night-piece on death (1722); Joseph Warton, com The enthusiast (1740); Robert Blair, com The Grave (1743); William Cole, com Ode to fear (1746); Edward Young, autor de Night Thoughts (1749-51), entre vários outros, fundamentais para pavimentar o gosto pelas questões inerentes à escuridão, morte, sobrenatural etc.

Diante de todo esse movimento, podemos dizer que The castle of Otranto dá continuidade e projeta com mais intensidade as questões iniciadas pelos poetas de cemitério. Na busca por uma forma híbrida, Horace Walpole revela no prefácio da segunda publicação do romance: "It was an attempt to blend the two kinds of romance, the ancient and the modern" ${ }^{\prime \prime 4}$ (WALPOLE, 2016, p. 8). A obra é responsável pela consolidação de um gênero ou modo ficcional, o Gótico, que se configura no campo da imaginação, quebrando as barreiras impostas pelo realismo e proporcionando uma experiência estética que faz evanescer a nossa segurança epistemológica. Walpole produziu seu novel tomando como matéria as características dos romances medievais, considerando o universo maravilhoso, as superstições e a fantasia. Mistura que confrontou as estruturas daquela sociedade ainda pautada nos preceitos clássicos e que exigia dos artistas uma preocupação com o decoro e com a verossimilhança, caros ao gênero romance, em ascensão naquele período.

A 'gothic story' proposta por Walpole e como continuidade do que era feito pelos poetas de cemitério serviu não apenas para 4 Foi uma tentativa de mesclar duas formas de romance, o antigo e o moderno. 
fomentar outros gêneros (o horror e o fantástico, por exemplo), outras possibilidades e modos de leitura, mas também para revelar os medos e assombros da nascente sociedade burguesa, ou seja, "[...] o romance gótico apenas exibe, portanto, as tensões e contradições inerentes à representação que a sociedade setecentista produziu de si mesma" (VASCONCELOS, 2002, p. 129). A estética pavimentada a partir do autor e pelos poetas tem muito do imaginário existente sobre a Idade Média, criado pelo Renascimento que a enxergava como um longo período de atraso e superstições; o gótico, nesse momento e na própria Inglaterra do século XVIII, significava "[...] tudo o que fosse antiquado, bárbaro, feudal e irracional, caótico, não-civilizado. O oposto de 'clássico', em resumo" (VASCONCELOS, 2002, p. 120).

Longe de querer uma definição para o gótico, podemos entendê-lo, grosso modo, como um 'gênero' transgressor que trinca a ordenação natural do mundo real, construindo um universo que, aparentemente, se distancia do mundo empírico, mas que, na verdade, diz muito sobre ele, tudo isso através dos confrontos entre as contradições que muito dizem sobre as deformidades da própria realidade, o que explica ser um fenômeno ambivalente (BOTTING, 2014; PUNTER; BYRON, 2014). Acerca disso, Hogle pontua: "Gothic fictions generally play with and oscilate between the earthly laws of convencional reality and the possibilities of the supernatural"5 (HOGLE, 2002, p. 2). É importante sublinhar que a mais antiga forma de narrativa é fantástica, discussão que foge do escopo do presente estudo, contudo, podemos lembrar que as

5 Ficções Góticas jogam, geralmente, com a oscilação entre as leis terrenas da realidade convencional e as possibilidades do sobrenatural. (Tradução nossa). 
teorizações sobre o fantástico (tomado como gênero) o entendem como nascido entre os séculos XVIII e XIX. Nomes como H. Mathey (1915), Tzvetan Todorov (1970), Joseph Restinger (1973), Irène Bessière (1974) etc., destacam-se nas teorizações a respeito do gênero. É juntamente com Júlio França que vamos entender a literatura gótica não como grupo de narrativas datado e limitado a um local e a uma época, mas sim "[...] como a confluência entre uma visão de mundo desencantada e uma linguagem artística bastante convencionalista e estetizada, que possui uma série de recorrências estilístico-textuais" (FRANÇA, 2017a, p. 186).

Isso dialoga com o dizer de Fred Botting, de que a estética negativa é o que caracteriza o gótico, colocando em xeque as fronteiras do conhecimento a medida em que invoca, através dos excessos da imaginação, o fenômeno sobrenatural. De acordo com o autor, "[...] gothic flights of imagination suggest supernatural possibility, mystery, magic, wonder and monstrosity"6 (BOTTING, 2014, p. 2), surgindo exatamente desse campo da desrazão para perturbar a realidade calma, o que reflete, como veremos, a própria estética fria criada pelas cores da série em estudo, mostrando que:

[...] the use of obscurity, the interplay of light and shadow, and the partial visibility of objects, in semidarkness, through veils, or behind screens, has a similar effect on the imagination: denying a clearly visible and safe picture of the world, disorientation elicits anxiety or extends a stimulating or scary sense of mystery and the unknown. ${ }^{7}$ (BOTTING, 2014, p. 6)

6 Voos góticos da imaginação sugerem possibilidades sobrenaturais, mistério, magia, o maravilhoso e monstruosidade.

7 O uso da obscuridade, a interação de luz e sombra e a visibilidade parcial de objetos, na semiescuridão, através de véus ou atrás de telas, tem um efeito semelhante na imaginação: negar uma imagem claramente visível e segura do mundo, desorientação 
Essa estética negativa da qual fala Botting se dá de forma dupla: pela deficiência (ausência, a exclusão ou negação do conhecimento, fatos ou coisas) e pelo excesso (seja das palavras, sentimentos, ideias ou imaginação). Trata-se da ruptura com os códigos das leis do conhecimento, isso constrói a ambivalência, que, de acordo com o autor, é uma inter-relação dinâmica do limite e da transgressão; assim, proibição e desejo sugerem que as normas, os limites e as fronteiras sejam também naturais sem se fixar absolutamente ou se manterem estáveis, apesar dos medos que eles engendram. Isso quer dizer que o gótico nega uma visão clara e segura do mundo, desorientação que gera ansiedade e prolonga o medo diante do misterioso e do desconhecido que são experimentados por personagens e leitores.

Diante disso, é importante lembrar que um traço distintivo do gótico ficcional é o sublime, conceito que Edmund Burke discute em Uma investigação filosófica sobre a origem de nossas ideias do sublime e do belo (1993), texto seminal para os estudos das artes e das estéticas. Para ele, o gosto está atrelado às faculdades da mente, que são influenciadas por um certo juízo a respeito das obras da imaginação e da arte. $\mathrm{O}$ autor acredita que as ideias do sublime e do belo não podem ser irredutíveis, ambas estão atreladas, não na concepção neoclássica que acreditava que o sublime estava em um grau maior do que o belo, aspecto que fez o autor refletir sobre os dois conceitos sob a perspectiva antropológica. Nessa empreitada, as categorias surgem como resultado do trabalho da imaginação. Para Burke, "[...] tudo que 
seja de algum modo capaz de incitar as ideias de dor e de perigo, isto é, tudo que seja de alguma maneira terrível ou relacionado a objetos terríveis ou atua de um modo análogo ao terror constitui uma fonte do sublime" (BURKE, 1993, p. 48).

Isso coloca o sublime como efeito condutor do gótico, que revela os excessos da imaginação, que parecem dar conta de uma consciência infinita no homem, que sente um certo temor exatamente por não se sentir capaz de dar conta de toda essa grandiosidade. Desta forma, esse efeito tem a função de construir, esteticamente, presságios que revelam o irreal diegético tendo em vista que se configura nas características que escapam ao comum, tudo isso em espaços cronotrópicos que se revelam ameaçadores. As reações estéticas promovidas pelo sublime envolvem a sensibilidade do receptor para que ele sinta a grandiosidade dos fenômenos extraordinários, gerados pelo ambiente inóspito e misterioso. De acordo com Júlio França:

Os loci horribiles da narrativa gótica são um elemento essencial para a produção do medo como efeito estético, já que expressam a sensação de desconforto e estranhamento que as personagens - $\mathrm{e}$, por extensão, o homem moderno - experimentam ante o espaço físico e social em que habitam. (FRANÇA, 2017b, p. 117)

Ao considerar o locus horribilis, a presença fantasmagórica do passado e a personagem monstruosa como elementos convencionais para a estrutura narrativa e a visão de mundo gótica, Júlio França, a respeito do segundo elemento, diz:

Sendo um fenômeno moderno, a literatura gótica carrega em si as apreensões geradas pelas 
mudanças ocorridas nos modos de percepção do tempo a partir do século XVIII. A aceleração do ritmo de vida e a urgência de se pensar um futuro em constante transformação promoveu a ideia de rompimento da continuidade entre os tempos históricos. Os eventos do passado não mais auxiliam na compreensão do que está por vir: tornamse estranhos e potencialmente aterrorizantes, retornando, de modo fantasmagórico, para afetar as ações do presente. Em uma de suas formas de enredo mais recorrente, o protagonista gótico é vítima de atos pretéritos, nem sempre por ele perpetrados. (FRANÇA, 2017b, p. 117-118)

É importante lembrar que no primeiro prefácio de The castle of Otranto, Horace Walpole construiu a figura de um tradutor fictício de nome William Marshal, que ao tomar partido da obra apresentada, diz: "I could wish he had grounded his plan on a more useful moral than this: that 'the sins of fathers are visited on their children to the third and fourth generation"8 (WALPOLE, 2016, p. 6). Sim, isso acontece na diegese do romance, mais especificamente com o personagem Manfred, "Prince of Otranto"9 (WALPOLE, 2016, p. 12), que perde a soberania quando forças sobrenaturais cumprem a profecia que deveria impedi-lo de se manter no poder, afinal, só ocupa essa posição elevada porque é um usurpador. É importante sublinhar que esse tema da maldição que paira sobre a família é bastante presente na tradição ocidental; a Bíblia, por exemplo, traz, no livro de Números, capítulo catorze, versículo dezoito, o seguinte: “O senhor é longânimo e grande em misericórdia, que

8 Eu gostaria que ele tivesse fundamentado o seu plano em uma moral mais útil do que esta: de que "os pecados dos pais são impostos aos filhos até a terceira ou quarta geração" (WALPOLE, 2016, p. 6, tradução nossa).

9 Príncipe de Otranto. 
perdoa a iniquidade e a transgressão, ainda que não inocenta o culpado, e visita a iniquidade dos pais nos filhos até à terceira e quarta gerações" (BÍBLIA, 2008, p. 159). Essa mesma característica é vista no capítulo trinta e quatro de Êxodo, versículo sete, que diz: “[...] que guarda a misericórdia em mil gerações, que perdoa a iniquidade, a transgressão e o pecado, ainda que não inocenta o culpado, e visita a iniquidade dos pais nos filhos e nos filhos dos filhos, até à terceira e quarta geração!" (BÍBLIA, 2008, p. 159).

Damos atenção a esse ponto, porque notamos que a relação entre passado e presente tornou-se um elemento basilar da maquinaria gótica, sobretudo nas primeiras produções do século XVIII. Por se mostrar longínquo e desconhecido, essa relação temporal ajuda na construção da ambivalência da produção artística, pois coloca os interlocutores em campos desconhecidos para insinuar o não dito, o invisível, aquilo que inquieta, de maneira a revelar personagens e figuras monstruosas ao longo dos acontecimentos. Isso mostra que, "[...] na narrativa gótica, vilões e anti-heróis são costumeiramente caracterizados como monstruosidades. As causas atribuídas à existência do monstro são variáveis - psicopatologias, diferenças culturais, determinantes sociais, a hybris do homem de ciência, entre outras" (FRANÇA, 2017b, p. 118, grifo do autor). Portanto, pensar o gótico ficcional é entender que se trada de um modo que rompe com as leis da probabilidade e com as fronteiras do conhecimento para invocar o obscuro e tudo o que nele existe.

Acerca dessa experiência proporcionada pelo gótico ficcional e de sua presença na série Desalma, podemos afirmar que se trata daquilo que Nöel Carroll identifica como 'horror artístico', 
“'horror' que serve de nome a um gênero que atravessa várias formas artísticas e vários tipos de mídia, cuja existência já é reconhecida na linguagem ordinária" (1999, p. 27). Essa concepção ajuda-nos a compreender o sentimento do espectador diante dos acontecimentos que ultrapassam o mundo real, bem como as propriedades desse gênero artístico que produz efeitos sobre o público. Carroll, ao defender sua tese de que o elemento ameaçador é a parte central do gênero narrativo horror, pontua:

Em relação ao horror artístico, algumas das sensações - ou agitações fisicamente sentidas, ou respostas automáticas, ou sentimentos - são contrações musculares, tensão, encolhimento, tremores, recuo, entorpecimento, enregelamento, paradas momentâneas, calafrios (portanto, "frios na espinha"), paralisias, estremecimentos, náusea, um reflexo de apreensão ou um estado de alerta fisicamente Incrementado (uma resposta ao perigo), talvez gritos involuntários etc. (CARROLL, 1999, p. 41)

Carroll pressupõe que o 'horror artístico' seja uma emoção, ou seja, a emoção que as narrativas e imagens de horror intentam no público, uma emoção cujos contornos se refletem nas respostas emocionais dos personagens humanos positivos aos monstros das histórias de horror, um estado emocional ocorrente, como pontua o autor, que entende que esse estado tem dimensões físicas e cognitivas. "Estar num estado emocional envolve a experiência de transição ou migração - uma mudança de estado, um mover-se para fora de um estado físico normal para outro estado agitado, marcado por mudanças interiores" (CARROLL, 1999, p. 41). Assim, é preciso que o estado emocional esteja sempre correlacionado 
com alguma perturbação física, experimentada pelo espectador de Desalma através do envolvimento que ele passa a ter com a trama, afinal,

nossas respostas emocionais às ficções, portanto, parecem implicar que acreditemos que os personagens de ficção existem, ao mesmo tempo em que também se pressupõe que os consumidores normais e informados de ficção não acreditam que os personagens de ficção existam. Sem dúvida, um modo de tentar explicar isso de uma maneira que dissipe a contradição é rejeitar a premissa de que os consumidores de ficção não acreditem na existência dos personagens de ficção. Isso poderia ser chamado de a teoria da ficção como ilusão. (CARROLL, 1999, p. 97)

Diante dessas questões, identificamos que Desalma busca agitar fisicamente seus espectadores, pois o que identifica e individualiza os estados emocionais são os seus elementos cognitivos, as emoções envolvem não apenas perturbações físicas, mas crenças e pensamentos. Assim, "os estados cognitivos diferenciam uma emoção de outra, embora para que um estado seja um estado emocional deva haver também algum tipo de agitação física que tenha sido gerada pelo estado cognitivo dominante (abarcando crenças ou pensamentos)" (CARROLL, 1999, p. 43). O autor pontua ainda que o estado emocional ocorrente constitui-se através de algum estado fisicamente anormal de agitação sentida, que é causado pela interpretação e pela avaliação cognitiva do sujeito acerca de sua situação, como veremos ao longo das discussões levantadas sobre a produção audiovisual em estudo. 


\section{NAS SENDAS DA TRAMA: DESALMA E O LOCUS HORRIBILIS}

No momento, Desalma tem apenas uma temporada de dez episódios que duram aproximadamente 45 minutos cada. Os episódios são nominados e dispostos da seguinte maneira: "Roman", "Fôlego", "Submersos", "Inocentes", "Tradições", "Revelações", "Halyna", "Ivana Kupala", "O retorno", "Desalma”. Foi criada e roteirizada por Ana Paula Maia e dirigida por Carlos Manga Jr., Pablo Muller e João Paulo Jabur. Para a composição das personagens, conta com atores e atrizes novatos e experientes, nomes como Cássia Kis (bruxa Haia), Cláudia Abreu (Ignes Burko) e Maria Ribeiro (Giovana) movimentam os acontecimentos centrais da tessitura audiovisual, como podemos visualizar no cartaz oficial, figura 1 , de divulgação da série:

Figura 1: Cartaz de divulgação da série

\section{original globoplay}

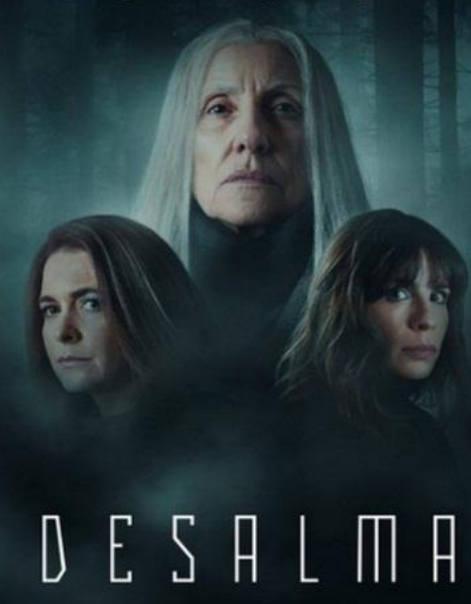

Fonte: Globoplay. 
A imagem acima comunica o místico em Desalma, produzida com uma fotografia densa. As cores frias se juntam com um tom escuro catalisando mistério, o indizível, a tristeza e o medo, de forma a construir uma atmosfera negativa (própria do gótico ficcional) que abriga o sobrenatural. Essa atmosfera paira sobre a cidade ficcional de Brígida e seus moradores, reverberando, por fim, no espectador, que se envolverá através de um estado emocional em sua dimensão física e cognitiva, como salienta Carroll (1999, p. 41). Ainda sobre o cartaz, é relevante sublinhar a presença da floresta, elemento fundamental na trama e que gera medo e contribui para a experiência aterrorizante. Não é à toa o lugar central ocupado pela bruxa Haia, que vive afastada do espaço citadino e que, através da magia, sempre está ligada ao sobrenatural.

A trama apresenta a trajetória dos moradores de Brígida diante dos fenômenos sobrenaturais que pairam sobre eles. Esse evento extraordinário que ronda as personagens no ano de 2018 tem relação com o assassinato da jovem Halyna (filha da bruxa Haia) durante a festa de Ivana Kupala em 1988. A morte da jovem fica associada à festividade, que é excluída do calendário festivo de Brígida. No entanto, trinta anos depois (2018), o povoado se prepara para recuperar e celebrar a festa, contudo, os preparativos indicam interferência na ordenação natural, os mistérios do passado assombram a cidade e seus moradores, que passam a ser assombrados por fenômenos sobrenaturais que conectam presente e passado.

Em Desalma, Brígida e suas florestas chamam atenção por serem lugares que causam insegurança, da mesma forma como nos textos góticos, que possuem espaços opressores que geram medo e 
inquietação nas personagens. Entendemos que esse elemento se mostra como força motriz capaz de emanar a cosmovisão gótica, cuja atmosfera negativa marca e reconhece o terror exatamente pelo efeito buscado: o medo. Tudo isso alinhado a uma sonoplastia que intensifica o clima de suspense, que, grosso modo, é um "[...] estado emocional que acompanha uma tal cena até o momento em que um dos resultados alternativos em competição é realizado" (CARROLL, 1999, p. 196).

Os espaços ameaçam as personagens porque se mostram como lugares onde o desconhecido habita e se manifesta. Em Desalma, temos uma força sobrenatural que se comporta como personagem monstruosa ao perseguir os moradores da cidade, cujos sentimentos guiam as reações dos espectadores, que experimentam esse 'horror artístico', conforme identificado por Nöel Carroll. Entendemos que as florestas de Brígida são marcadas como lugares sombrios não convencionais que escondem o desconhecido, são lugares do perigo, bem como da relação com o passado, estratégia narrativa que amplia o medo do que não pode ser visto. $\mathrm{O}$ elemento espaço fomenta o medo à medida que se revela sombrio e carregado por questões inquietantes, fazendo as personagens se movimentarem de acordo com o que nele surge. O elo com o desconhecido intensifica-se através da forma imbricada da trama, que é construída sob um jogo temporal que mescla acontecimentos de 2018 e 1988, estratégia narrativa que reforça a indissociabilidade entre presente e passado, vida e morte, realidade e fantasia. Portanto, identificamos os espaços diegéticos de Desalma como lugares do medo e da opressão. Brígida e as florestas à sua volta são espaços enunciativos que 
abrigam e comunicam o sobrenatural, uma cidade tradicional antiga repleta de lendas e segredos, suas florestas são obscuras e místicas, características que intensificam a atmosfera negativa existente no lugar. A seguir trazemos duas imagens (figura 2 e 3) para mostrar esse funcionamento:

Figura 2: Abertura de Desalma

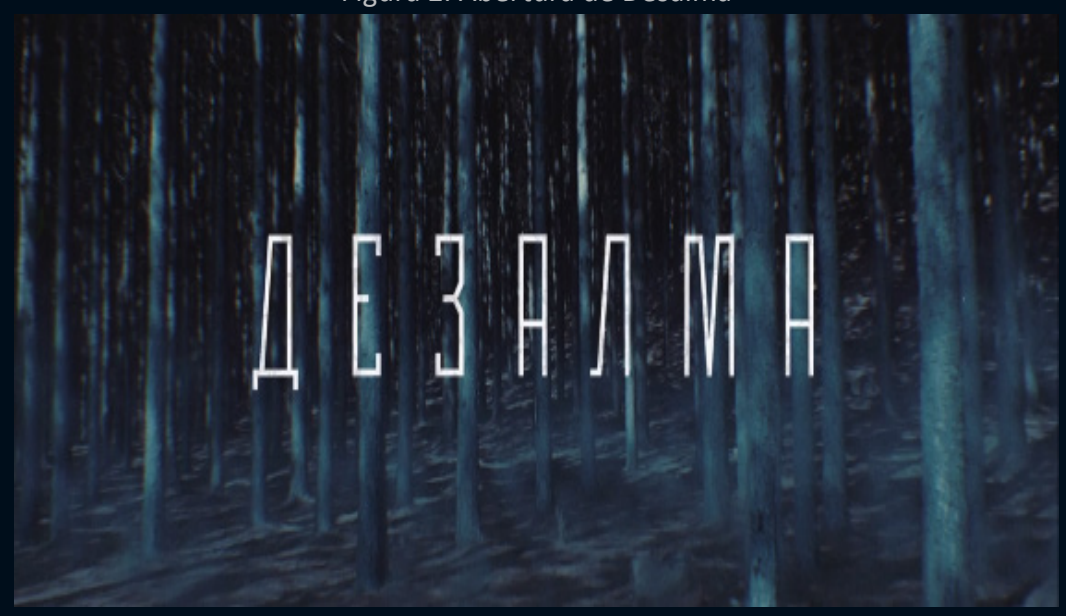

Fonte: Globoplay.

Figura 3: Entrada da cidade de Brígida

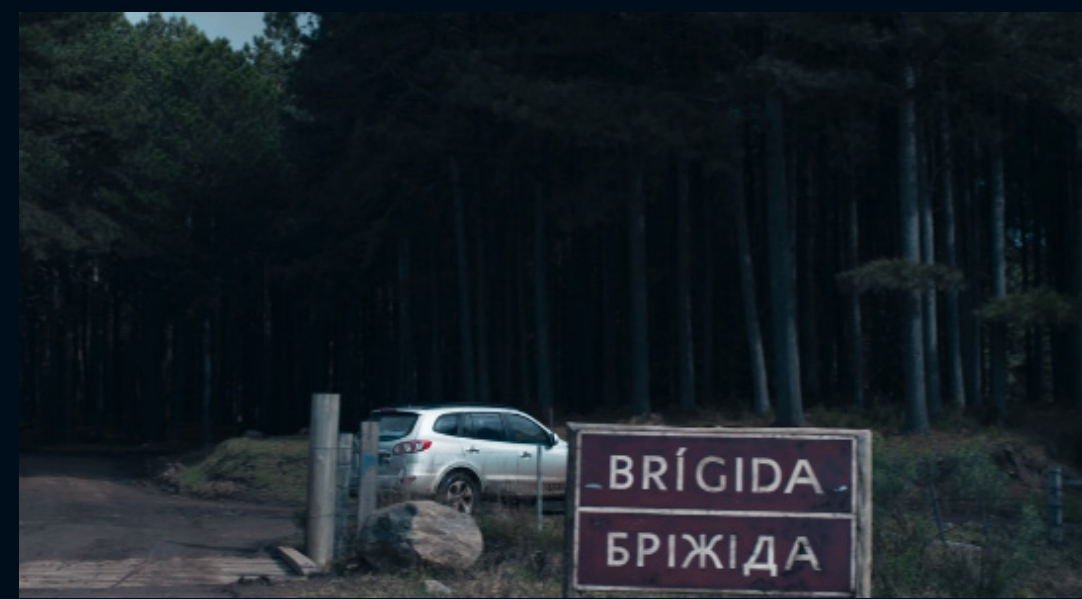

Fonte: Globoplay. 
A imagem referente à abertura, figura 2, dialoga com o cartaz de divulgação, figura 1, apresentado inicialmente. Nela contemplamos a presença de neblina ou fumaça, que estão em movimento na floresta, uma clara menção aos espíritos que habitam o lugar. Ao longo da abertura, as letras que formam a palavra 'desalma' se desfazem de forma evanescente, reafirmando a fluidez e a característica movediça e mística das matas que assombram o vilarejo, onde tudo é incerto. A imagem seguinte, figura 3, mostra a entrada da cidade, o primeiro contato de quem chega em Brígida é com a miscelânea natural. Atravessar - lugar para chegar no espaço urbano é adentrar no campo do misterioso, onde tudo é guiado pelo místico. É notória a frequência, a intensidade e a densidade com que esses espaços se impõem no conjunto da trama de Desalma. O carro presente na imagem pertence à personagem Giovana, é o momento que ela e suas filhas estão chegando em Brígida. O percurso no interior da floresta é acompanhado pelo espectador, que, assim como elas, sente a atmosfera sombria do lugar, tudo isso através de jogo de imagens e sons que mostram as particularidades labirínticas do espaço, que faz alusão a algumas presenças invisíveis.

Podemos dizer que Brígida (com seus casarões antigos) e suas florestas se mostram como extensões delas mesmas, cenários enunciativos altamente assustadores (com características mórbidas, assombrosas, opressoras etc.) que geram conflitos na medida em que exercem forte influência no rumo da vida e no comportamento das personagens que transitam entre elas e sempre são observadas pela presença invisível. Os lugares ficam cada vez mais violentos através da relação com a própria festa 
de Ivana Kupala, que contribui para a construção de sentidos negativos nesses espaços. Identificamos que o evento festivo age como um trauma na vida dos moradores, pois a chegada do dia da comemoração atua como um agouro que reforça o imaginário coletivo acerca dessa festividade desconfortável para eles porque ela une presente e passado.

Para a construção da cosmovisão gótica em Desalma, notamos a presença do folclore ucraniano, ou melhor, de toda a fantasia que ronda o imaginário popular desse povo. Contudo, é importante ressaltar que Desalma não pretende recuperar os elementos da tradição eslava para ser fiel a ela, mas considerá-la para, através da criação artística, suscitar o medo no espectador, sentimento primitivo, universal e avassalador, a busca é por um efeito estético. Sobre isso, não podemos deixar de mencionar os estudos de Xavier Aldana Reyes, especialista em filmes, ficções góticas e de terror. O livro Horror: A Literary History, organizado por ele, por exemplo, apresenta, através dos textos, um percurso cronológico desse gênero na ficção, investigando seu desenvolvimento ao longo dos anos.

A festa Ivana Kupala é uma tradição eslava que celebra o Sol. As pessoas se adornam com flores, fazem uma grande fogueira (símbolo de purificação), dançam e cantam ao redor dela. Os camponeses acreditavam que nessa noite, considerada a mais curta do ano, ninguém deveria dormir, pois as bruxas, os espíritos malignos, feiticeiros, espíritos da floresta, estavam todos soltos, elementos folclóricos presentes em Brígida e em suas florestas. Na Ucrânia pré-cristã, essa festividade era, de fato, um rito de fertilidade que asseguraria boa colheita; a festa marca o final do 
solstício de verão e o início da safra, contudo, foi proibida pelo cristianismo. Destaca-se que ao longo do dia os meninos e as meninas confeccionavam bonecos de Merena e Kupalo, eles eram queimados ou jogados no rio, porque as pessoas acreditavam que as almas iriam se encontrar em outro plano, com esse gesto garantiriam a perpetuação da espécie humana. As meninas também queimavam ervas especiais com o intuito de atrair sorte no amor e na colheita.

Essas questões fazem-nos pensar sobre a representatividade do folclore para uma cultura, bem como o quanto diz sobre ela. De acordo com Frederico Edelweiss, "[...] o Folclore, o saber popular, são, em resumo, as manifestações variadas da alma popular através das ideias e dos sentimentos coletivos, inconscientemente feitos e refeitos através dos tempos" (EDELWEISS, 2001, p. 20). Com Frederico Edelweiss entendemos que os iniciadores da ciência limitaram o folclore a um campo apenas das lendas e contos de fadas. Contudo, aos poucos começa-se a perceber que nesses relatos havia muito mais que fantasia, como, por exemplo, experiências de sobrevivências reais, de crenças e costumes de antanho. Como diz Edelweiss,

as fadas e os bruxos, os gigantes e os anões, benfazejos ou malvados, eram velhas divindades ou personagens poderosas da sua corte celestial que, banidas pela religião romana, a princípio, e depois pelo cristianismo, foram aos poucos relegadas ao rol das superstições ou criações poéticas. (2001, p. 21)

O autor chama atenção ainda para o lugar evocado pelo folclore. Não se trata de multidões, espaços citadinos, mas de 
regiões menos trepidantes, com uma população menor, em suas palavras, "[...] quanto menor tiver sido o contato com o automóvel, o avião e o rádio, tanto mais genuínos serão os fatos que se nos apresentam" (EDELWEISS, 2001, p. 22). Brígida é tipicamente esse lugar menos trepidante, pois estar na floresta, sobretudo, na noite de Ivana Kupala, significa expor-se aos espíritos e às forças sobrenaturais, isso mostra que:

[...] os ambientes são capazes de inspirar medo não apenas em decorrência de suas características concretas, físicas, mas dependem das percepções subjetivas que os indivíduos têm dos lugares. Tais percepções, entretanto, não são apenas idiossincráticas, mas respondem a determinadas condições culturais. (FRANÇA, 2015, p. 6)

Assim, Brígida e suas florestas não são, portanto, espaços de harmonia, pois são responsáveis por lembrarem seus moradores a todo momento da força invisível que deles toma conta e que sempre está presente. Um exemplo disso é a chegada de Giovana e suas filhas Melissa e Emily, personagens acostumadas com a movimentação de São Paulo, oposto de Brígida.

É interessante notar que, no início da narrativa, Giovana tem uma filosofia de acreditar apenas no que pode ser visto e tocado, contudo, aos poucos, no decorrer dos acontecimentos, isso muda, devido a vivenciar os mistérios que atravessam a cidade, o que a faz rever seus princípios e ideias sobre aquilo que até então considerava superstição popular. Desde quando chega em Brígida, a todo momento é colocada em situações que revelam determinados estados emocionais, é importante lembrar que "[...] as emoções envolvem não só perturbações físicas, mas também 
crenças e pensamentos, crenças e pensamentos acerca das propriedades dos objetos e das situações" (CARROLL, 1999, p. 43).

Para visualizarmos isso, remetemos à cena em que Bóris explica para Giovana sobre Ivana Kupala e todos os mistérios que rondam a festa; depois ele afirma que Brígida é uma cidade cheia de mistérios. Por fim, ele pergunta se ela acredita em Deus, ela responde: "Digamos que estou sendo convencida da existência dele", ${ }^{10}$ o que caracteriza mudança na personagem, diante dos segredos descobertos e acontecimentos que a colocam diante do sobrenatural. Isso é cada vez mais visível quando ela percebe que Emily começa a ter comportamentos estranhos, que indicam a presença de espíritos, mais especificamente o de Halyna, não apenas querendo se apossar do corpo da garota, mas também se vingar da família Skavronski. Um desses vários momentos é mostrado na cena em que a criança começa a ouvir seu nome sendo sussurrado; hipnotizada, ela é atraída para o rio que corta a cidade, Emily estava sendo induzida à morte, o ato não acontece porque ela é despertada pelos latidos de seu cachorro.

Ao longo dos episódios, notamos que Giovana se abala com os acontecimentos irracionais que tomam conta de Brígida e suas florestas, isso mostra que é na relação com o indizível que o medo nela e nas demais personagens é construído, são colocadas em estado fisicamente anormal de agitação, que será interpretado pela avaliação cognitiva das personagens acerca da situação, "[...] esse é o núcleo de um estado emocional [...]", diz Carroll (1999, p. 44). Isso permite-nos concordar com Zygmunt Bauman, que diz:

10 Fonte: Globoplay. 
O medo é mais assustador quando difuso, disperso, indistinto, desvinculado, desancorado, flutuante, sem endereço nem motivo claros; quando nos assombra sem que haja uma explicação visível, quando a ameaça que devemos temer pode ser vislumbrada em toda parte, mas em lugar algum se pode vê-la. "Medo" é o nome que damos à nossa incerteza: nossa ignorância da ameaça e do que deve ser feito - do que pode e do que não pode para fazê-la parar ou enfrenta-a, se cessá-la estiver além do nosso alcance. (BAUMAN, 2006, p. 8)

Brígida e suas florestas ameaçam a segurança epistemológica por serem lugares fechados, densos, gélidos e labirínticos, a dimensão espacial introspectiva reforça a instabilidade dos moradores, que funcionam como joguetes do próprio espaço lúgubre. Desta forma, "as reações emocionais dos personagens fornecem, pois, uma série de instruções, ou melhor, de exemplos sobre a maneira como o público deve responder aos monstros da ficção - ou seja, sobre a maneira como devemos reagir a suas propriedades monstruosas" (CARROLL, 1999, p. 33). Há uma sinergia entre essas particularidades que se entrelaçam e criam o clima de tensão e assombro, inquietando a todos. Ter contato com Brígida e suas florestas é saber que a ameaça está presente, ponto que amarra o elo entre Desalma e o gótico, este que, conforme Sandra Vasconcelos, "[...] tem a ver com a estimulação e a representação do medo [...]" (2002, p. 132). É importante destacar que os espaços não são tomados por uma atmosfera negativa que apenas sugere a presença sobrenatural, mas é por eles e através deles que esse elemento age na vida das personagens, como veremos a seguir. 


\section{O PASSADO RECLAMA E ASSOMBRA O PRESENTE}

A relação temporal entre presente e passado, constante nos gêneros terror e horror, estrutura Desalma, reforçando a indissociabilidade entre vida e morte, como podemos perceber na fala de Haia, no primeiro episódio, e que se mostra pertinente e elucidativa. Essa personagem, que mora em um casebre distante do vilarejo, pratica rituais de magia e sempre é procurada pelos moradores da cidade, que buscam magia, curadora etc. Em uma consulta, ela diz: "Até a morte pode ser revertida, se tiver paciência de lidar com o tempo. O tempo... É uma invenção para controlar a vida". ${ }^{11}$ A mulher que está ali se consultando questiona se a Haia pode trazer alguém da morte, a resposta é a seguinte: "A morte também é uma ilusão, assim como o tempo. Tudo que existiu uma única vez, jamais deixará de existir". ${ }^{12}$

Essa relação temporal se mostra ambivalente e obscura, conectada com o indizível e sempre sugerindo presenças sobrenaturais que despertam angústia e terror. Isso se intensifica a partir do momento em que começamos a perceber que o espírito de Halyna sempre esteve presente para se vingar da família Skavronski, sentimento que parece ser alimentado por Haia, que tem a magia como meio para punir a família, não é aleatório Roman Skavronski, Anatoli Skavronski Burko, Emily Skavronski e Melissa Skavronski serem os alvos dessa vingança. Tudo indica que Halyna sempre desejou a alma de Roman, uma espécie de acerto de contas entre a jovem assassinada e a família Skavronski.

11 Fonte: Globoplay.

12 Fonte: Globoplay. 
Isso nos remete ao início da série, exatamente com a morte de Roman. A trama inicia com uma imagem fria e panorâmica, nossos olhos acompanham um carro em movimento (dirigido por Roman) por uma estrada cheia de curvas nas montanhas da Serra Catarinense, ao som de uma música melancólica que parece anunciar algo ruim. Tratase da canção popular ucraniana chamada "Plyve kacha", interpretada pela atriz e cantora Bella Leindecker. A letra apresenta um diálogo entre mãe e filho indo para a guerra. Um dos propósitos da canção é afirmar que, enquanto as guerras existirem, músicas tristes sempre existirão, o que faz sentido em Desalma, sobretudo na cena inicial, em que acompanhamos o suicídio de Roman.

O personagem estaciona o carro em um lugar deserto da floresta; aparentemente perturbado, ele caminha até o alto de uma cachoeira, onde, em ucraniano, pronuncia as seguintes palavras traduzidas: "Não era pra ter acontecido. Nós erramos. Éramos jovens, estúpidos"13. Em seguida, em português, diz: "Me perdoa, Halyna. Nós não podíamos ter feito aquilo"14, e se joga lá de cima. Uma clara referência ao que ele fez em 1988, quando ele e Halyna eram namorados. Durante a festa de Ivana Kupala daquele ano, a jovem descobre que Roman tinha um caso com Bóris Burko; ela consegue fotografar os dois se beijando; ao perceberem o que ela tinha feito, os meninos a perseguem. Durante a fuga, Halyna encontra Aleksey Skavronski, primo de Roman, um jovem inconsequente que era apaixonado por ela. Ele tenta agarrá-la à força, derrubando-a brutalmente no chão; na queda, ela bate a cabeça e desmaia. Assustado e acreditando que tinha matado a jovem, ele enche a 
mochila dela com várias pedras e afunda a menina nas águas da cachoeira. Toda a cena é assistida por Roman e Bóris, que estavam escondidos. Quando Aleksey sai do lugar do crime, os meninos decidem recuperar a fotografia que acabaria com a reputação deles. Nesse momento, Halyna dá um suspiro profundo; amedrontados e com a certeza de que se ela sobrevivesse contaria tudo sobre eles, os meninos a afundam. Nos episódios finais, descobrimos que meses antes do suicídio, Roman tinha procurado a bruxa Haia para que ela fizesse o ritual de transmigração de alma, pois ele estava muito doente e não queria morrer. Desde então, parece que sua alma fica perdida nesse processo, até encontrar o corpo de Anatoli Skavronski. Haia sabe que Roman já estava amaldiçoado (por Halyna) antes mesmo de procurá-la.

Além de Roman, outro elemento essencial na trama é apresentado nesse momento: a água, cuja simbologia diegética, acreditamos, significa fluidez, continuidade, movimentação, por isso a série chamar Desalma, a alma que deságua em outra morada, o que implica dizer que tudo o que existiu, jamais deixará de existir, conforme pontuado por Haia, reforçando ainda mais o elo entre o antes (passado) e o agora (presente). A água simboliza a relação com a própria origem da vida, a cura, a fertilidade, a regeneração, o nascimento, a transformação, a mudança, ponto que inicia o segmento da vida, tudo o que Roman queria; portanto, é nessa relação sacra que ela figura na tessitura ficcional de Desalma, é o caminho que movimenta as almas, o que explica a presença desse elemento ao longo de toda a trama.

Essas observações podem ser pensadas juntamente com Gaston Bachelard em A água e os sonhos, em que ele reflete 
sobre uma das quatro substâncias descobertas por Empédocles na antiga Grécia: o fogo, a água, a terra e o ar. Ao enxergá-las como primitivas ao homem e aos seus sentimentos, Bachelard se volta para a substância água, entendendo-a não apenas como matéria, mas como uma realidade poética completa, exatamente por ser elemento das misturas. Para ele, não podemos olhá-la de maneira simplista, tampouco considerá-la apenas matéria importante para a sobrevivência, pois as águas significam e têm significados, cheiros, vozes, sabores, cores. Nas palavras do autor:

[...] a água é realmente o elemento transitório. É a metamorfose ontológica essencial entre o fogo e a terra. O ser votado à água é um ser em vertigem. Morre a cada minuto, alguma coisa de sua substância desmorona constantemente. A morte cotidiana não é a morte exuberante do fogo que perfura o céu com suas flechas; a morte cotidiana é a morte da água. A água corre sempre, a água cai sempre, acaba sempre em sua morte horizontal. Em numerosos exemplos veremos que para a imaginação materializante a morte da água é mais sonhadora que a morte da terra: o sofrimento da água é infinito. (BACHELARD, 1997, p. 7)

Para compreendermos o funcionamento desses sentidos em Desalma, é importante atentarmos ao título da obra, cuja palavra existe a partir de uma prefixação e que nos permite dividi-la em duas partes: 'des' e 'alma', ponto que configura a presença do duplo na produção. Recorremos ao dicionário Houaiss, que traz as seguintes definições: "Des - pref. 1. 'separação, afastamento': descascar, desenterrar. 2. 'oposição, negação': desamor, desnortear. 3. 'aumento, reforço': desinfeliz" (HOUAISS, 2004, p. 218). Para 'alma', tem-se: 
Al.ma s.f. 1 REL parte imortal do homem; espírito cf. corpo. 2. Natureza moral e emocional de uma pessoa <era uma a. revoltada> 3 ser humano <é uma boa a.> 4 caráter de uma pessoa ou grupo $<a$ a. do povo italiano 5 fonte de animação ou liderança <ela é sempre a a. das festas> 6 expressão de emoção ou sentimento <cantar com $a$ a.> 7 infrm. fantasma 8 infrm. condição essencial <o segredo é a $a$. do negócio> 9 peça de couro colocada entre a palmilha e a sola do calçado 10 interior oco de arma de fogo, que vai da parte interior da câmara da carga até a boca. (HOUAISS, 2004, p. 32, grifos do autor)

Os prefixos, em síntese, são elementos mórficos que se juntam a um radical para que uma nova palavra seja criada. A aglutinação é capital nesse processo que revela a relação entre dois elementos semânticos para formar novas palavras, a exemplo da palavra desalma, constituída pelo prefixo 'des' + o substantivo 'alma', cuja formação prefixal anuncia, ao mesmo tempo, ausência e presença de alma, que aponta para a duplicidade, existente na série, por meio de: Roman e Anatoli, passado e presente, Halyna e Melissa. Esse sentido construído no título da trama e que se manifesta nos dez episódios é o fio condutor que mantém vivo o elo entre vida e morte. Conexão que é estabelecida no primeiro episódio, quando Roman se mata e dois meses depois presenciamos a manifestação de sua alma em Anatoli Skavronski Burko. Isso é sugerido na cena em que Anatoli está tomando banho na banheira de sua casa, de repente o chaveiro que pertencia ao personagem que se matou cai ali dentro, logo o espectador identifica a quem pertence aquele objeto. A partir desse momento, o elo, entre os dois, é estabelecido. 
Anatoli é um menino que se transforma em uma figura assustadora, obscura. Nessa relação com a ausência de uma forma humana, podemos dizer que a criança tem a sua alma afastada de seu corpo para que a de Roman se manifeste nele. Isso pode ser visto na cena em que o menino está na sala de aula sentado ao lado de Emily (filha de Giovana). Eles trocam os desenhos, o menino pergunta quem era o homem com asa presente no desenho dela. Ela diz que é o pai e que ele tinha ido morar no céu. Diante disso e com um olhar macabro, o menino diz: "Não foi não. Ele está aqui", a voz manifestada não é a da criança, e sim a do próprio Roman, que quer se manter presente entre os humanos, contudo, o comportamento da criança deixa claro que esse processo parece não estar se dando de maneira tranquila, pois tudo indica que as almas de ambos brigam por espaço, no corpo de Anatoli. Podemos lembrar do momento em que Anatoli, que repetitivamente desenha um cavalo preto (em referência ao cavalo da família que se chama Veludo), encontra-se sozinho e de frente para o animal. A mãe, ao perceber o sumiço do filho, logo chega ao lugar onde ele estava; de repente, ele diz para ela que o animal disse que iria matá-lo. Não se trata de invenção ou imaginação infantil, mas sim da relação sobrenatural que pairava sobre Anatoli; conforme o desenvolvimento dos episódios, o menino induz o cavalo à morte.

Outro momento que revela falha no ritual é quando Anatoli desaparece dentro do consultório da psiquiatra de sua mãe, Ignes. Ela tratava de uma depressão porque ainda não tinha superado a morte do irmão Aleksey Skavronski, que havia sido condenado, no passado, pela morte de Halyna. É interessante destacar que ao longo da narrativa ficamos sabendo que Aleksey Skavronski, após 
cumprir a sua pena na cadeia pelo assassinato de Halyna, morre em um acidente; teve sua cabeça decepada e nunca fora encontrada. Contudo, no último episódio descobrimos que a bruxa Haia o manteve preso ao longo de todos esses anos, o tempo dele como prisioneiro fora cumprido, conforme a sua vingança, após isso, ela o solta. Isso reafirma a necessidade de vingança contra a família Skavronski, como indicamos inicialmente.

No consultório, ambas procuram Anatoli e o encontram sob o chuveiro, todo molhado e com um olhar profundo. A psiquiatra questiona se ele está com medo de algo, e ele responde: "Eu não. Ele está"15, e aponta para o espelho, onde havia a marca de uma mão sobre o vapor, cena que subtrai não apenas a compreensão das personagens, mas também a do espectador, que a experimenta de forma inquietante na mesma proporção que Ignes e a psiquiatra. Isso, como pontua Todorov, mostra que "[...] a intervenção do elemento sobrenatural constitui sempre uma ruptura no sistema de regras preestabelecidas e nela encontra justificação" (TODOROV, 2010, p. 174). Vale destacar que após esse momento a psiquiatra liga para alguém e avisa que Anatoli era o alvo. Não sabemos com quem ela fala, entretanto, tudo indica ser com Haia, pois ao longo dos episódios descobrimos que a médica é também uma bruxa.

Para Haia, "[...] a água é o melhor condutor para a magia [...]". ${ }^{16}$ A água se mostra como representativa desse processo de desalma, que nos permite entendê-lo como passagem fluida (ou pelo menos deveria ser) da alma para o corpo, uma vez que, segundo Bachelard, 
"[...] a água tem também vozes indiretas. A natureza repercute ecos ontológicos. Os seres respondem-se imitando vozes elementares. De todos os elementos, a água é o mais fiel "espelho das vozes"' (BACHELARD, 1997, p. 199).

A afirmação de Bachelard dialoga com a cena em que Anatoli é encontrado afogado na piscina da escola. As cenas desse momento se entrecruzam, pois ora visualizamos a mãe recebendo o telefonema anunciando o acontecido, ora a imagem do menino estático na piscina, ambas são revestidas por um terceiro elemento, a voz da bruxa Haia dizendo: "Ele estava ali na calmaria daquelas águas. Tentando um caminho de volta, apesar de saber que não há caminho de volta". ${ }^{17}$ De forma abrupta, o menino é puxado por uma força sobrenatural para o fundo da piscina, evidenciando, portanto, a presença de Halyna, que está atrás da alma de Roman; toda a cena é revestida por uma sonoplastia que confere terror à trama, reforçando cada vez mais a presença do espírito da jovem. É como se Haia fosse responsável pela punição dos vivos (o que explica ter mantido Aleksey Skavronski preso por tanto tempo) e Halyna responsável pela punição espiritual (ela deseja a alma de Roman e se manifesta no corpo de Melissa, como veremos).

A personagem Haia é uma figura central em Desalma. É importante destacar que no mesmo ano da morte da filha, a senhora tinha acabado de perder o marido, que trabalhava como caminhoneiro na empresa de Viktor Skavronski, que insistia em não indenizá-la pela morte do esposo. Entendemos que ela é uma personagem enlutada que nutre ódio pelos Skavronski ao longo desses trinta anos, afinal tudo indica que ela sabe que os culpados 17 Fonte: Globoplay. 
pela morte de sua filha pertencem a essa família. Ao longo da narrativa, é sugerido que ela seja a responsável pela maldição que paira sobre os Skavronski, juntamente com o espírito de Halyna, que quer se vingar.

Ainda nessa relação, não podemos deixar de destacar a cena em que algo bate na porta da casa de Haia; ao abri-la, encontra a bolinha amarela do chaveiro de Roman. Já no interior de sua casa, de repente um vulto passa rapidamente, é a imagem de Anatoli. Em seguida, a porta do banheiro se fecha sozinha, quando Haia a abre, nota que a torneira está ligada e a banheira transbordava muita água. Ao se abaixar e passar a mão sobre a água, a personagem é surpreendida por uma mão que a toca; logo em seguida, vê marcas de passos no chão, como se alguém tivesse acabado de sair do local. Mais uma vez, observamos o recurso de alternância entre cenas, pois ora vemos Anatoli, ora Haia. Por fim, é a imagem de Anatoli que ela enxerga ali dentro da banheira. Parece que a alma de Roman almeja a ajuda dela. Tudo isso se configura como sendo consequência da presença de Halyna.

Desta maneira, podemos afirmar que o espírito de Halyna se comporta como as personagens monstruosas das narrativas góticas, pois sua presença e seu desejo por vingança caracterizam a sua monstruosidade, uma vez que a represália de Halyna começa a prejudicar o corpo de Anatoli, que aos poucos adoece e parece caminhar para a morte. Levando em consideração as discussões de Carroll, podemos dizer que essa figura monstruosa passa a ser um importante objeto da emoção horror, pois essa figura precisa ser reconhecida pelo público como um ser ameaçador. O que horroriza não está nas categorias sociais, o que explica o espírito da jovem, 
que vive longe do contato humano. A presença do espírito da jovem se manifesta exatamente no ano em que a cidade de Brígida, após trinta anos, resolve comemorar a antiga tradição, ponto que reforça o imaginário negativo sobre a festividade. O momento é propício para Halyna se fazer presente porque se trata da noite de Ivana Kupala, a noite mais escura do ano e que é considerada portal para que espíritos malignos, bruxas e demônios sejam livres. Diante disso, podemos dizer que a narrativa de Desalma opera o escopo da razão e do conhecimento visto que moldura perspectivas parciais, de forma a abalar a segurança das personagens e dos espectadores, suscitando medo, terror, horror, repulsa, esteticamente falando.

Nos momentos finais da narrativa audiovisual, Ignes, orientada por Haia, consegue salvar Anatoli, tudo através do mesmo ritual de transmigração de alma feito em Roman. Porém, no exato momento ritualístico, Bóris aparece e é morto ao ser possuído pelo espírito que habitava o corpo de seu filho. Enquanto é levado pelo rabecão, de repente, o defunto começa a se mover, o motorista e seu acompanhante se assustam, param o carro e ficam paralisados. Ivan Burko (irmão do falecido), que estava logo atrás acompanhando o carro funerário, desloca-se até eles para averiguar o que estava acontecendo. Ao abrirem a parte de trás do automóvel, o corpo, como se tivesse afogado levanta e solta muita água pela boca (e aqui observamos mais uma vez a presença do elemento água). Assustado, Ivan diz que aquilo era um milagre. No entanto, Bóris responde: "Eu não sou o Bóris. Eu sou o Roman". ${ }^{18}$ A cena é cortada para a bruxa Haia, que pressente e parece ver o que está acontecendo.

18 Fonte: Globoplay. 
A presença de Halyna nesses momentos finais é concretizada, uma vez que ela encontra morada no corpo de Melissa, o que parece ter sido anunciado quando em uma certa noite a filha de Giovana e seus amigos resolveram fazer um ritual. Em um momento, cada um deveria se olhar no espelho, com o intuito de receber algum contato sobrenatural. Quando chegou a vez de Melissa, ela se assustou ao ver a imagem de uma menina (Halyna), acontecimento que estreita sua ligação com a família Skavronski.

No final do último episódio, Halyna escolhe o corpo da jovem para se manifestar. Isso se dá quando na noite de Ivana Kupala a pequena Emily se perde na floresta. Contudo, Melissa desaparece assim que encontram a criança. Algum tempo depois, ela é vista caminhando, com um olhar perdido e cantarolando uma música popular e tradicional na Ucrânia, que se chama "Mapycя" (Marusia). A canção traz características folclóricas ucranianas que são compartilhadas na Rússia e com países eslavos ocidentais. Por pertencer ao popular, não se sabe quem é o autor da canção, cuja letra faz referência ao nome Marusia Bohuslavka, uma heroína lendária que pode ter vivido na Ucrânia ou no século XVI ou XVII. A história popular ucraniana conta que a jovem foi capturada pelos turcos e comercializada para um harém, contudo, passou a ter confiança do marido e começou a libertar vários cossacos (kozak, palavra que origina do turco kazak, o significado original era "homem livre"), mas ali ela permaneceu por estar disposta a viver naquela situação. Assim, os ucranianos passaram a alimentar fortes laços por ela.

O policial (sobrinho de Haia e também bruxo) a encontra e a cena é reveladora ao sugerir que não era Melissa quem estava ali, 
e sim Halyna. Em seguida, há um corte de cena para a bruxa Haia que, com um olhar misterioso, diz: "Seja bem vinda, Halyna", ${ }^{19}$ ela sabia que a filha estava de volta. Assim, a vingança da jovem se concretiza porque ela, agora, tem no mesmo corpo, as almas de Bóris e Roman, responsáveis pela sua morte em 1988. Isso explica o nome do último episódio, em que isso acontece, se chamar "Desalma", um processo que dá a entender que é cíclico e não irá cessar por ali, de maneira a fundir passado e presente.

Por fim, podemos dizer que as personagens se mostram como sujeitos que vivem um trauma coletivo, acarretado pela morte de Halyna em 1988 e que foi recalcado ao longo desses trinta anos. Todavia, a comemoração da festa de Ivana Kupala reascende aquilo que deveria permanecer desconhecido, ponto que parece dialogar com a ideia de unheimlich (inquietante), pensada por Freud. Para ele, "[...] o inquietante é algo que deveria permanecer oculto, mas apareceu" (FREUD, 2010, p. 360). O que é considerado desconhecido e que volta de forma potente, não se trata de algo novo, mas sim familiar, ou seja, aquilo que por algum motivo ou trauma deveria manter-se recalcado, mas surge com uma força que reflete alguma angústia já sofrida no passado, como acontece em Desalma. A morte de Halyna cria esse trauma coletivo, afinal, a aproximação da festa de Ivana Kupala, que inquieta os personagens, se mostra "[...] aquela espécie de coisa assustadora que remonta ao que é há muito conhecido, ao bastante familiar" (FREUD, 2010, p. 331), reverberando, por fim, no espectador, que ao longo dos dez episódios, experimenta e desenvolve sentimentos desconfortáveis inerentes à inquietude dos personagens, a noite de Ivana Kupala 
cria fissuras na ordenação natural para que o passado reclame e assombre o presente. Desalma é a representação do desassossego.

\section{CONSIDERAÇÕES FINAIS}

O percurso investigativo do presente estudo se ocupou em analisar a série Desalma à luz do gótico ficcional, partindo de alguns elementos, como o locus horribilis e o passado que volta para assombrar o presente, ambos revestidos pela atmosfera negativa que caracteriza o gótico. A escolha da série se deu porque a produção audiovisual brasileira, ao apelar para o drama sobrenatural, filia-se ao terror, elemento fundamental para a experiência do medo no espectador, que vivencia o místico, o obscuro, através de acontecimentos gerados por espaços inóspitos e imbricados ao sobrenatural.

É importante salientar que Desalma é um produto que por si só representa a consistência e o espaço dos serviços de streamings na atualidade e que são fundamentais para construir o hábito e gosto do público, que tem buscado cada vez mais por esses serviços on-demand; Desalma representa o desafio das empresas que se lançam no meio digital e que buscam exclusividade. Essa realidade só revela o espaço conquistado pelo serviço de streaming nos últimos dez anos, o que nos permite pensar na própria relação entre o espaço da internet e o público, que se mostra cada vez mais tomado, motivado e influenciado pelo mercado digital, que precisa ser ágil para dar conta do consumo voraz de conteúdo realizado pelo consumidor, que é exigente e demanda atualizações rápidas.

Toda essa popularização das produções audiovisuais deve muito ao desenvolvimento do cinema (e também o teatro) no 
século $X X$, com as projeções realistas, mas que anunciavam o nascimento de uma nova maneira de produzir material artístico, o que hoje conhecemos por cinema. É fato que o espaço cinematográfico foi crucial para as repetições e desenvolvimento de elementos que até então eram vistos apenas na literatura, essa que foi fundamental para tornar o cinema a sétima arte. Além disso, o aparecimento da rádio e da televisão também foi crucial para a difusão de elementos e formatos que até então existiam apenas no universo literário.

Por mais que os avanços tecnológicos sejam expressivos, é possível observar que as produções audiovisuais ainda mantêm o mesmo formato, sobretudo as novelas e as séries, que seguem a estrutura dos folhetins do século XIX. Além disso, notamos que os elementos discutidos em Desalma se inscrevem na tradição do gótico ficcional, mostrando que essa estética não pode ser compreendida como datada, o que acontece porque está bastante atrelada às questões modernas. Na verdade, estamos falando de uma tradição artística elaborada que encena os medos e assombros da própria sociedade.

Como salientamos inicialmente, é curioso uma emissora brasileira recorrer ao gênero terror, visto que suas produções não seguem essa linha, afinal a ideia de realismo ainda é cara ao gótico. Acerca disso, Júlio França lembra que a crítica literária da primeira metade do século XIX, decisiva para o entretenimento, sempre se baseava na percepção de entender a literatura atrelada aos espaços geográficos do Brasil, o que fez com que a produção literária beneficiasse a identidade nacional, ponto que contribuiu para um olhar preconceituoso que fez com que "[...] a ficção gótica 
e literatura brasileira sejam incompatíveis [...]" (FRANÇA, 2017b, p. 112); portanto, tudo o que não revelasse as características brasileiras, era deixado de lado, é por isso que o gótico, de certa forma, foi excluído, contudo, nosso percurso investigativo mostrou que a tradição do gótico ficcional mantém-se viva na atualidade. Assim como o mundo, o gótico tem se transformado e ganhado novos contornos, espaços e dimensões. Desalma merece atenção porque ao se inscrever nessa tradição ajuda a difundi-la e abrir caminhos para outras produções nacionais, fazendo com que o Brasil entenda que não é preciso dar atenção apenas ao que é de fora, mas também ao que é produzido aqui. Desalma mostra que o interesse por essa estética no âmbito nacional é grande, não é à toa que, devido ao grande sucesso, a série foi renovada para ter sua segunda temporada.

\section{REFERÊNCIAS}

ARANTES, P. Arte e mídia no Brasil: perspectivas da estética digital. ARS, São Paulo, [S. I.], v. 3, n. 6, p. 52-65, 2005. Disponível em: https://www.revistas.usp. br/ars/article/view/2941. Acesso em: 15 jan. 2021.

BACHELARD, Gaston. A água e os sonhos: ensaio sobre a imaginação da matéria. Tradução de Antônio de Pádua Danesi. São Paulo: Martins Fonte, 1997.

BAUMAN, Zygmunt. Medo Líquido. Rio de Janeiro: Zahar, 2008.

BíBLIA. Traduzida em Português por João Ferreira de Almeida. 2. ed. São Paulo: Sociedade Bíblica do Brasil, p. 1536, 2008.

BOTTING, Fred. Gothic. London; New York: Routledge Taylor \& Francis Group 2014.

BURKE, Edmund. Uma investigação filosófica sobre a origem de nossas ideias do sublime e do belo. Tradução, apresentação e notas de Enid Abreu Dobránszky. São Paulo: Papirus, 1993.

BYRON, Glennis; PUNTER, David. The Gothic. United Kingdom: Blackwell Publishing Ltd, 2004. 
CARROLL, Nöel. A filosofia do horror ou paradoxos do coração. Tradução de Roberto Leal Ferreira. Campinas: Papirus, 1999.

DESALMA. Direção: Carlos Manga Jr, João Paulo Jabur, Pablo Muller. Produção: Globoplay. Brasil: Globoplay, 2020. Disponível em: https://globoplay.globo. com/. Acesso em: 09 dez. 2020.

EDELWEISS, Frederico. Apontamentos de folclore. Salvador: EDUFBA, 2001. FRANÇA, Júlio. As sombras do real: a visão de mundo gótica e as poéticas realistas. In: CHIARA, Ana; ROCHA, Fátima Cristina Dias. (Orgs.) Literatura Brasileira em Foco VI; em torno dos realismos. Rio de Janeiro: Casa Doze, 2015. FRANÇA, Júlio. O gótico e a presença fantasmagórica do passado. Anais eletrônicos do XV encontro da ABRALIC, v. 1. Rio de Janeiro: Dialogarts, p. 2492-2502, 2016.

FRANÇA, Júlio. Aspectos góticos na estrutura narrativa de "Sarapalha", de Guimarães Rosa. Nonada, Porto Alegre, v. 2, n. 29, p. 185-200, 2017a.

FRANÇA, Júlio. O sequestro do Gótico no Brasil. In: FRANÇA, Júlio; COLUCCI, Luciana (Org.). As nuances do gótico: do setecentos à atualidade. Rio de Janeiro: Bonecker Editora, p. 111-124, 2017b.

FREUD, Sigmund. O inquietante. In: FREUD, Sigmund. História de uma neurose infantil ("O homem dos lobos"), além do princípio do prazer e outros textos. Tradução de Paulo César de Souza. Rio de Janeiro: Companhia das Letras, 2010. GROOM, Nick. The gothic: a very short introduction. United Kingdom: Oxford University Press, 2012.

HAMMOND, M.; MAZDON, L. The Contemporary Television Series. Edinburgh: Edinburgh University Press, 2005.

HOGLE, JERROLD E. Introduction: the Gothic in western culture. In: HOGLE, Jerrold E. (Org.). Gothic fiction. New York: Cambridge University Press, 2002. HOUAISS, Antonio. Minidicionário houaiss da língua portuguesa. 2. ed. Rio de Janeiro: Objetiva, 2004.

LOVECRAFT, Howard Phillips. O horror sobrenatural em literatura. Tradução de Celso M. Paciornik. São Paulo: Iluminuras, 2007.

MONTEIRO, Maria Conceição. Na aurora da modernidade: a ascensão dos romances góticos e cortês na literatura inglesa. Rio de Janeiro: Caetés, 2004. 
ROSSI, Aparecido Donizete; SÁ, Luiz Fernando Ferreira (Org.). O Gótico e suas interseções teórico-críticas. Rio de Janeiro: Dialogarts, 2014.

SÁ, Daniel Serravalle de. Gótico tropical: o sublime e o demoníaco em 0 guarani. Salvador: EDUFBA, 2010.

SCHLÜTZ, Daniela M. Contemporary Quality TV: the Entertainment Experience of Complex Serial Narratives. United Kingdom Annals of the International Communication Association, 40:1, p. 95-124, 2015. Available at: https://www.tandfonline.com/doi/abs/10.1080/23808985.2015.11735257. Accessed on: $15^{\text {th }}$ Jan. 2021.

SILVA, Marcel Vieira Barreto. Cultura das séries: forma, contexto e consumo de ficção seriada na contemporaneidade. Galaxia, São Paulo, n. 27, p. 241-252, jun., 2014.

SMITH, Andrew. Gothic literature. Endinburgh: Endinburgh University Press, 2007.

TODOROV, Tzvetan. Introdução à literatura Fantástica. Tradução de Maria Clara Correa Castello. 4. ed. São Paulo: Perspectiva, 2010.

VASCONCELOS, Sandra Guardini T. A formação do romance inglês: ensaios teóricos. São Paulo: Hucitec, 2007.

VASCONCELOS, Sandra Guardini T. Dez lições sobre o romance inglês do século XVIII. São Paulo: Boitempo, 2002.

WALPOLE, Horace. The castle of Otranto. Florianópolis: UFSC, 2016.

WHEATLEY, Helen. Gothic Television. 2002. Tese (Doutorado em Filosofia) Department of Film and Television Studies. University of Warwick, United Kingdom 2002. 